\title{
Blasts 5 Percent or More of Bone Marrow Nucleated Cells
}

National Cancer Institute

\section{Source}

National Cancer Institute. Blasts 5 Percent or More of Bone Marrow Nucleated Cells. NCI

Thesaurus. Code C136411.

A microscopic finding indicating the presence of blasts constituting at least $5 \%$ of the nucleated cells in a bone marrow aspirate. 